Research, part of a Special Feature on Sustainable Land-Use Practices in Mountain Regions: Integrative Analysis of Ecosystem Dynamics Under Global Change, Social-Economic Impacts, and Policy Implications

\title{
Dynamics of Forage Production in Pasture-woodlands of the Swiss Jura Mountains under Projected Climate Change Scenarios
}

\author{
$\underline{\text { Konstantin S. Gavazov }}^{1,2}, \underline{\text { Alexander Peringer }}^{1,3}, \underline{\text { Alexandre Buttler }}^{1,2}, \underline{\text { François Gillet }}^{1,4}$ and Thomas Spiegelberger $^{1,5}$
}

\begin{abstract}
Silvopastoral systems of the Swiss Jura Mountains serve as a traditional source of forage and timber in the subalpine vegetation belt, but their vulnerability to land use and climate change puts their future sustainability at stake. We coupled experimental and modeling approaches to assess the impact of climate change on the pasture-woodland landscape. We drew conclusions on the resistance potential of wooded pastures with different management intensities by sampling along a canopy cover gradient. This gradient spanned from unwooded pastures associated with intensive farming to densely wooded pastures associated with extensive farming. Transplanted mesocosms of these ecosystems placed at warmer and drier conditions provided experimental evidence that climate change reduced herbaceous biomass production in unwooded pastures but had no effect in sparsely wooded pastures, and even stimulated productivity in densely wooded pastures. Through modeling these results with a spatially explicit model of wooded pastures (WoodPaM) modified for the current application, results were extrapolated to the local landscape under two regionalized Intergovernmental Panel on Climate Change scenarios for climate change. This led to the suggestion that within the Jura pasture-woodlands, forage production in the near future (2000-2050 AD) would be affected disproportionately throughout the landscape. A stable forage supply in hot, dry years would be provided only by extensive and moderate farming, which allows the development of an insulating tree cover within grazed pastures. We conclude that such structural landscape diversity would grant wood-pastures with a buffering potential in the face of climate change in the forthcoming decades.
\end{abstract}

Key Words: aboveground biomass; drought; ecotone; grassland; pasture; silvopastoral system; subalpine; transplantation; woodland

\section{INTRODUCTION}

\section{History and importance of pasture-woodlands}

Pasture-woodlands are a traditional human-made landscape in European mountains (Etienne 1996) and cover a major part of the Swiss Jura Mountains. They consist of a mosaic of open grassland, closed forest, and semi-forested pastureland with scattered or clumped trees, and owe their shape to a long history of multifunctional land use, mainly pasturing and forestry (Buttler et al. 2009). Wood-pastures are true ecotones between closed forests and open grassland, and thus are more than just a simple interface between those two vegetation types. In such silvopastoral ecosystems, grasslands and woodlands are intimately associated in space and time as the result of a balance between counteracting ecological processes (Gillet et al. 2002, Gillet 2008). Forest encroachment and its suppression by browsing of livestock and extensive pasture management leads to a spatio-temporal heterogeneity of the landscape, defined by disturbance regimes, microclimate, and topography, and provides favorable conditions for high biodiversity (Gillet et al. 1999, Dufour et al. 2006).

At present, pasture-woodlands vary substantially in the amount and quality of ecosystem services they provide. Economically important factors such as forage supply are maintained higher through intensively managed treeless pastures than through extensive wood-pastures with free grazing livestock. This is important for local farmers who, from a socioeconomic view, are the main users of wooded pastures, and as such, may deliberately shape the landscape into an unwooded one. Apart from farming, in some regions, revenues generated from forestry activities may be substantial (Gillet and Gallandat 1996). The significance of this landscape for the tourist economy has also been acknowledged, though it remains difficult to measure (Miéville-Ott and Barbezat 2005).

The coexistence of pastureland and woodland in a single and diverse silvopastoral ecosystem is not easy to preserve and calls for integrated management schemes (Barbezat and Boquet 2008 ). Both intensification and extensification of the current land use may lead to a breakdown of this precarious association, resulting in a segregation of woodland and grassland (Buttler et al. 2009). Even though anthropogenic land use change has been considered to be a major threat for mountain ecosystems worldwide (Körner et al. 2006), little is known about its interaction with climate change in the future.

Climate change in the European mountains

Global warming and associated environmental changes are

\footnotetext{
${ }^{1}$ Ecole Polytechnique Fédérale de Lausanne EPFL, School of Architecture, Civil and Environmental Engineering ENAC, Laboratory of ecological systems ECOS, ${ }^{2}$ Swiss Federal Institute for Forest, Snow and Landscape Research WSL, ${ }^{3}$ University of Stuttgart, Institute for Landscape Planning ILPOE,

${ }^{4}$ University of Franche-Comté - CNRS, UMR 6249 Chrono-environnement, ${ }^{5}$ IRSTEA, Research Unit Mountain Ecosystems
} 
predicted to have a strong impact on mountain ecosystems this century (IPCC 2007). The observed trend in Swiss mountains during the 20th century for a $1.5 \mathrm{~K}$ rise in mean annual air temperature (Beniston et al. 1997) is paralleled by increased instances of extreme summer temperature maxima and prolonged droughts (Schär et al. 2004, Beniston 2009). Throughout the current century these tendencies are predicted to become more pronounced, and northern hemisphere temperate mountains will experience the most intensive temperature rise with a rate of warming typically two to three times higher (range $+2.8 \mathrm{~K}$ to $+5.3 \mathrm{~K}$ ) than that recorded over the 20th century (Nogues-Bravo et al. 2007). Alongside, predicted hot spells and a 30\% diminishing precipitation during the growing season will intensify the dry periods in Central Europe (Beniston et al. 2007, CH2011). These will bring about changes in summer soil moisture availability, plant phenology, and growing season length, which would ultimately have repercussions on ecosystem distribution and function (Parry 2000, FOEN/FSO 2011).

\section{Response of plant communities to climate change}

Episodic extreme climate events, such as summer heat waves, have strong and distinct impacts at the landscape scale (Ciais et al. 2005, Reichstein et al. 2007, Teuling et al. 2010). A mechanistic understanding of primary ecological processes occurring in a heterogeneous landscape such as pasturewoodlands is therefore essential for efficient management. Currently, there is a wealth of literature, encompassing various experimental methodologies, about the effects of warmer and drier climate on pristine cold-adapted vegetation. Transplantation experiments along natural climatic gradients offer a powerful method for testing hypotheses about how species and communities are affected by future climatic changes. Although relatively few published studies have used this technique, some successful attempts at contrasting terrestrial environments have been carried out: in peatlands (Wieder and Yavitt 1994, Breeuwer et al. 2010), in boreal forests (Hobbie and Chapin 1998), in montane meadows (Bruelheide 2003), in subalpine grasslands (Sebastia 2007), and in alpine vegetation (Scheepens et al. 2010). The results from those studies, however, outline idiosyncratic patterns of plant community responses to environmental change. Concerning plant aboveground biomass, recent studies have reported an increase in annual herbaceous biomass production with warmer and drier climate (Bruelheide 2003, Sebastia 2007). Others (Harte and Shaw 1995, Zhang and Welker 1996), to the contrary, have observed no cumulative change in aboveground biomass. Drought alone has been found to exert a negative effect on plant biomass (Johnson et al. 2011). At the level of plant community composition, these studies fail to give a holistic picture of shifts in diversity resulting from a climate manipulation. Either graminoids or forbs have been shown to successfully dominate after a climatic perturbation. Opportunistic plants may be granted competitive advantage through advanced phenological development (Dunne et al. 2003, Körner 2003, Inouye 2008), or through utilization of newly available nutrient resources (Bowman et al. 2006, Soudzilovskaia et al. 2007). Other plants may benefit from their inherent tolerance of specific environmental stress (Buchner and Neuner 2003, Brock and Galen 2005). Overall, more fertile early successional grassland communities have been shown to be more responsive to climate warming and drought, compared to late successional ones, typically found in areas of low intensity management (Grime et al. 2000). Drought resistance and recovery potential of plant communities have also been attributed to high species richness (van Ruijven and Berendse 2010, Mariotte et al. 2013), whereas grazing of highland pastures has been shown to both promote herbaceous richness and reduce evapotranspiration loss and thus water consumption (Körner et al. 2006). In comparison to grasslands, forests exhibit more conservative water use, and hence cope better with long-lasting heat and drought stress (Teuling et al. 2010).

In light of these findings, and given the heterogeneous landscape structure and high biodiversity of pasturewoodlands, we suspect that the productivity of such a mosaic of forest and extensively grazed diverse mountain grassland communities could be robust to the effects of heat and drought.

\section{Upscaling from experimental plots to landscape level}

Inspired by the work of Dunne et al. (2004), which demonstrates the challenging but beneficial task of extrapolating experimental results on ecosystem response to climate change from the scale of plots to that of landscapes, in this study we coupled an experimental with a modeling approach. We believe that such combinations of observational, manipulative, and modeling techniques are highly adapted to assessing ecosystem vulnerability or resilience to environmental change (Spiegelberger et al. 2012).

To this aim, we established a transplantation experiment along an altitudinal gradient to derive the response of plant communities of open grassland, semi-wooded pastures, and grazed forests to climate manipulation (warming of up to +4 $\mathrm{K})$. We built the results on biomass production into a dynamic simulation model of wood-pasture ecosystems in order to assess the impact of drought events on forage provision for livestock at the landscape level and in the proximate time frame of climate change projections (until $2050 \mathrm{AD}$ ).

\section{Hypotheses}

We hypothesized that (1) herbaceous aboveground biomass (AGB) production in characteristic plant communities from wood-pastures would be more stable under climate change than in those from treeless grasslands. Based on this hypothesis at plot level, we predicted (2) that landscape-scale forage production in wood-pastures would be more stable during projected heat wave periods than in intensively managed unwooded pastures. At last, (3) we put forward the hypothesis 
that wooded pastures represent a more robust land use form than conventional treeless pastures, considering future climate change impacts.

\section{METHODS}

\section{Study area and design of the warming experiment}

The Combe des Amburnex in the Swiss Jura Mountains is a characteristic subalpine area of pasture-woodlands situated within the boundaries of the Park Jurasien Vaudois. The climate is predominantly oceanic with a mean annual rainfall of ca. $1750 \mathrm{~mm}$ at 1350 meters above sea level (m ASL) (including more than $450 \mathrm{~mm}$ of snow precipitation) and a mean annual temperature of $4.5^{\circ} \mathrm{C}$. The ground is generally covered with snow from November to May.

In August 2009, three wooded pastures of similar area lying along the Combe des Amburnex at $1350 \mathrm{~m}$ ASL were chosen according to their tree canopy cover, which resulted from different intensity of land use. These were, in increasing order of management intensity, a densely wooded pasture, a sparsely wooded pasture, and an unwooded pasture. The pastures were situated within $1 \mathrm{~km}$ of each other, each measured about 2 ha, and all shared the same geomorphology, microtopography, and aspect. Within each of the three pasture types, 15 plots were randomly selected to represent the characteristic herbaceous vegetation of the respective area. To allow for a transplantation of soil turfs, plots were divided into 12 separate $20 \mathrm{~cm} \times 20 \mathrm{~cm}$ and $30-\mathrm{cm}$ deep soil cores and were assembled back into rectangular PVC boxes of $60 \mathrm{~cm} \times 80 \mathrm{~cm}$ and $30 \mathrm{~cm}$ height. Chunks of intersected tree roots (diameter $>1 \mathrm{~cm}$ ) were removed from the soil cores, and the remaining gaps were filled in with adjacent soil from the same horizon. The resulting 45 mesocosms were left in place until the end of the vegetation season to recover from the excavation, and then were transported to their receptor sites in October 2009. In total, three transplantation sites were established along an altitudinal transect: Combe des Amburnex (1350 m ASL, 46 $54^{\prime} \mathrm{N}, 6^{\circ}$ 23' E), Saint-George (1010 m ASL, 46 $52^{\prime}$ N, 6 6 26' E), and Arboretum d'Aubonne (570 m ASL, 46 $51^{\prime}$ ' N, 6 ${ }^{\circ} 37^{\prime}$ E). The first site at $1350 \mathrm{~m}$ ASL served as a control site with unchanged climate. The site at $1010 \mathrm{~m}$ ASL was chosen to represent a combination of annual temperature increase of $+2 \mathrm{~K}$ and a precipitation decrease of $-20 \%$. The site at $570 \mathrm{~m}$ ASL represented a combination of annual temperature increase of $+4 \mathrm{~K}$ and a precipitation decrease of $-40 \%$. These preliminary approximations were derived from interpolated data from nearby weather stations. At each site, 15 mesocosms, thus representing five replicates of each pasture type and all originating from the Combe des Amburnex, were transplanted following a completely randomized design. The boxes were dug down to surface level into previously prepared trenches, thus preventing lateral heat exchange with the atmosphere. Mesocosms with turfs from sparsely wooded pastures and densely wooded pastures were shaded using two types of UV- resistant nylon mesh, which reduced photosynthetic active radiation by $40 \%$ and $80 \%$, respectively, thus simulating fieldmeasured light conditions in the corresponding habitats during the 2009 growing season (unpublished data). The mesh fabric was suspended on wooden frames $50 \mathrm{~cm}$ above the ground surface and did not intercept rain precipitation. Those remained in the field only during the snow-free period of the year in order to avoid interference with the snowpack. As a means of keeping the grazing pressure on the plots and avoiding a confounding effect of "abandonment" and accumulation of standing litter, plots were clipped close to ground level at the end of the vegetation growing season.

Herbaceous biomass was harvested at the end of July 2010 during the first year after turf transplantation, and served as an estimate of annual AGB production. At each plot, the vegetation within a fixed area of $35 \mathrm{~cm} \times 35 \mathrm{~cm}$ was cut down to ca. $1 \mathrm{~cm}$ above the soil surface, determined to species level, dried at $70^{\circ} \mathrm{C}$ for $48 \mathrm{~h}$, and weighed.

Climate parameters were monitored continuously throughout the experiment by means of one automated weather station (Sensor Scope Sàrl, Switzerland) per experimental site, which measured at a one-minute interval air temperature and humidity $2 \mathrm{~m}$ above the ground surface, as well as rain precipitation. $\mathrm{ECH}_{2} \mathrm{O}$ EC-TM sensor probes coupled to Em50 data-loggers (Decagon Devices, Inc., USA) recorded soil temperature and volumetric water content at topsoil horizon $(0$ to $-3 \mathrm{~cm})$ every minute, and data were averaged over onehour intervals. Data presented here are given for the months of the 2010 growing season-April, May, June, July, August, and September.

\section{Statistical analysis of experimental data}

The experimental design allowed for the explanation of annual variation in herbaceous biomass during the first year after transplantation by four factors: two categorical ones-initial pasture type and altitude of the transplantation site, and two continuous physical ones-soil temperature and soil moisture. Each of the two edaphic variables was averaged per plot over the growing season (between respective soil thaw and day of harvest), thus integrating the microclimate conditions experienced by the plants. An ANCOVA model was fit through the raw data to test the significance of single factors and their two-way interactions. Assumptions of normality and homoscedasticity of the residuals were verified visually using diagnostic plots.

In order to extrapolate from experimental plot data, obtained under a distinct set of environmental conditions, to continuous site gradients in real landscapes, we built a linear regression model to predict the seasonal AGB production from the two continuous variables - tree cover percentage and degrees of temperature change. The experimental shading of the plots was related to tree cover as follows: 0\% shading (light extinction under the canopy) for unwooded pasture with $0 \%$ 
Table 1. Vegetation types of the herb layer and simulated environmental factors under which they emerge, as well as their pastoral value, from which a first estimate of biomass production is calculated.

\begin{tabular}{|c|c|c|c|c|}
\hline & Grazing intensity & Dunging intensity & Tree cover & Pastoral value $\mathrm{PV}^{\dagger}$ \\
\hline Eutrophic pasture & High & High & Low & 40 \\
\hline Oligotrophic pasture & High & Low & Low & 20 \\
\hline Fallow & Low & Low & Low & 10 \\
\hline Understory & Low & Low & High & 40 \\
\hline
\end{tabular}

tree cover, $40 \%$ shading for sparsely wooded pasture with $50 \%$ tree cover, and $80 \%$ shading for densely wooded pasture with $100 \%$ tree cover. Temperature change was calculated as the difference between local plant growing season temperature and that at the control site at $1350 \mathrm{~m}$ ASL during the experimental year 2010. The parameter estimates for those factors retained in the optimal model fit were incorporated into the landscape model of wooded pastures WoodPAM.

All statistical analyses were performed using R version 2.13.1. (R Development Core Team 2012).

\section{Spatially explicit simulation model of wood-pasture ecosystems WoodPaM}

The dynamic simulation model of wooded pastures, WoodPaM, was developed by Gillet et al. (2002) and Gillet (2008) to investigate the successional dynamics of wooded pastures in the Swiss Jura Mountains. WoodPaM is a spatially explicit ecosystem model. As such, it is able to simulate the emergence of a semi-open landscape structure due to selective grazing of large herbivores (cattle) by explicitly considering the food chain from primary productivity to forage consumption by livestock. During simulations, selective foraging by cattle causes local impacts on vegetation (i.e., grazing, browsing, dunging, and trampling). Those, in turn, and together with geomorphologic and climatic conditions, promote or hinder forest development, and by this means drive the development of the landscape structure.

In WoodPaM, a pasture is represented by an arrangement of quadratic, 25-m wide, grid cells (Fig. 1). In each cell the vegetation is represented by an herb, a shrub, and a tree submodel. Succession in the herb layer is driven by the intensity of grazing and dunging, as well as by tree cover. As such, the herbaceous vegetation is categorized in the following four vegetation types-eutrophic pasture, oligotrophic pasture, fallow, and understory, which differ in pastoral value (PV) (Table 1). A first estimate of yearly forage production "P" in a grid cell is computed based on a new regression model (in comparison to Gillet [2008]), which relates empirical data on productivity from the same set of vegetation surveys from the Jura Mountains and the Alps as used in Gillet (2008) to the pastoral value "PV" and the length of the vegetation growing period "vegdays", with:
$\mathrm{P}=$ yearly forage production $\left(\mathrm{t} \mathrm{DM} \cdot \mathrm{ha}^{-1} \cdot \mathrm{a}^{-1}\right)$

$\mathrm{PV}=$ average pastoral value of the herb layer in the grid cell, weighted by the relative cover of vegetation types vegdays $=$ length of the vegetation growing period (days) $\mathrm{fpm}=$ maximal production $\left(20 \mathrm{t} \mathrm{DM} \cdot \mathrm{ha}^{-1} \cdot \mathrm{a}^{-1}\right)$ $\mathrm{fpi}=$ "initial" production for $\mathrm{PV}=0\left(8.5 \mathrm{t} \mathrm{DM} \cdot \mathrm{ha}^{-1} \cdot \mathrm{a}^{-1}\right)$ $\mathrm{ra}=$ altitude effect on the growth coefficient $\left(2.152 \cdot 10^{-5}\right)$ $\mathrm{rm}=$ maximal growth coefficient for $\mathrm{A}=0(0.05)$

During simulations, the first estimate of yearly forage production was calculated from the current pastoral value of the vegetation types in each grid cell and the average length of the vegetation growing period during the last 50 simulation years. By this means, we took into account that the productivity of grassland plant communities increases slowly following the general trend of temperature rise (Fig. 2) rather than spontaneously in single warm years. In the second case, a drought effect has to be expected, which we addressed separately.

As a further innovation in comparison to former versions of WoodPaM (see Gillet 2008, Peringer et al. 2013), we modified the first estimate of forage production by applying a multiplier " $D$ " for the drought effect of high average temperatures in the vegetation growing period during hot years. This modifier was calculated from the regression model of AGB response to transplantation along the climate warming gradient (see Methods:Statistical analysis and Results: Effects of increased temperature). No modifier was applied in cooler years because the transplantation experiment did not deliver data for climate cooling. The temperature anomaly " $\Delta \mathrm{T}$ " is the difference between the average temperature of the current vegetation growing period and the long-term mean temperature of the vegetation growing periods during years 1961-2010 (the experiment took place in year 2010, thus plant communities are adapted to recent past climate). Because the regression function also expresses the dependency of productivity on tree cover (low forage production of understory in comparison to grassland), the pastoral value of understory was set equal to the value of grassland (Table 1). The combined impact of drought and tree cover was computed according to Eq. 1: 
$D=$

$(55.670-3.291 \Delta T-0.456$ TreeCover +0.070 TreeCover $\Delta T) / 55.670$, for $\Delta T>0$

$D=1$, for $\Delta T \leq 0$

Thus, the final yearly forage production in each cell, taking into account the slow prolongation of the vegetation growing period and yearly positive anomalies in the average temperature of the vegetation growing period, was computed as the product of $P$ and $D$.

Fig. 1. Grassland-forest mosaic in year 2000 of the simulated pastures, as estimated by aerial photograph interpretation by M. Kalbermatten (see Chételat et al. this issue): the almost treeless intensively grazed pasture Les Planets Ouest (IWP), the moderately grazed pasture Planets Milieu Est (MWP), and the extensively grazed true mosaic pasture Les Cluds Sud (EWP).

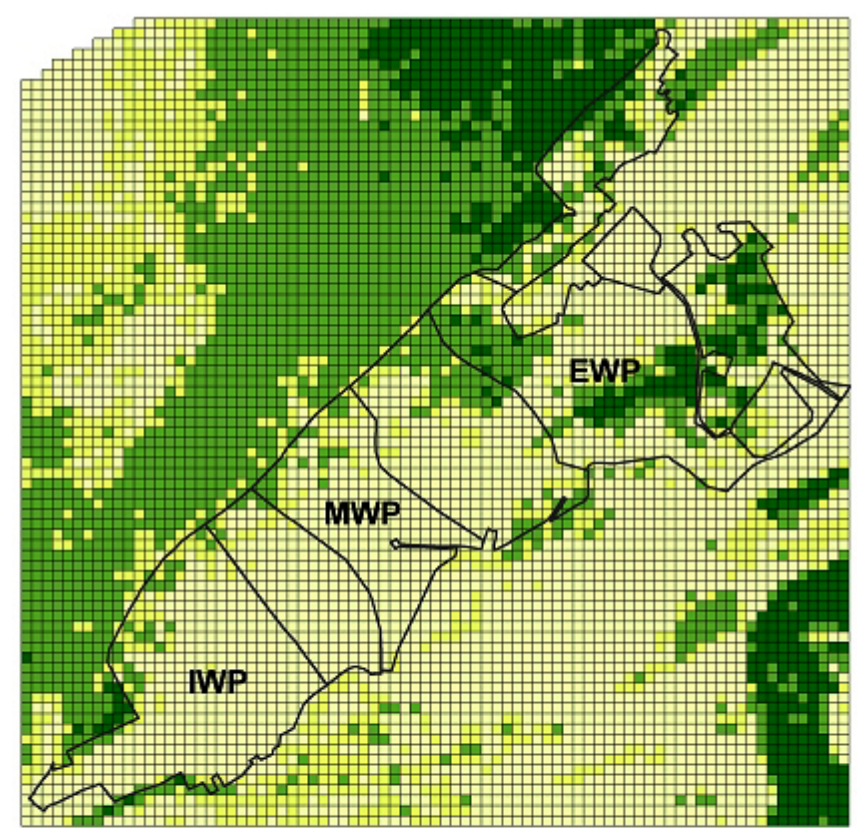

Unwooded Pasture Sparsely Wooded Pasture

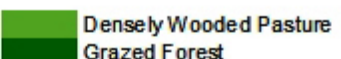

Grazed Forest
This model modification assumed that (1) the productivity of mountain grassland communities slowly increases with the increasing length of the vegetation growing period experienced during the last 50 years (community adaptation); however, (2) their productivity in extraordinarily hot years is consistently reduced by drought. We set the current climate (Fig. 2) as a baseline for the estimation of the drought impact because we did not expect the development of new (drought resistant) genotypes, especially because grasslands are dominated by perennial species and species immigration is slow.

Fig. 2. Regionalized observed (1950-2000 AD) and simulated (2000-2050 AD) annual temperatures (thin solid lines) and vegetation growing season temperatures (thick solid lines) for two scenarios from the Intergovernmental Panel on Climate Change Special Report Emissions Scenarios (IPCC-SRES 2000): B2 (dark grey) and A1FI (light grey). The average temperature of the vegetation periods from 1961 to 2010 is presented as a reference threshold (thick dashed black line). The difference between simulated yearly temperatures of vegetation periods and this reference threshold is implemented as a parameter $\Delta \mathrm{T}$ driving drought stress in simulations. The average temperature of the last 50 years (thin dashed line) is used to simulate the increase in productivity due to the prolongation of the vegetation period.

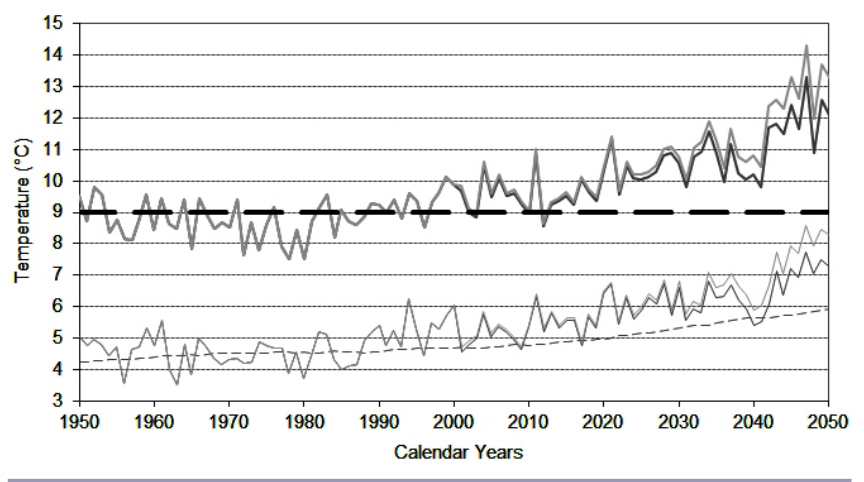

Consequently, simulated forage production per grid cell is a function of the successional state of the herb layer (pastoral value of vegetation types), the average length of the vegetation growing period during the last 50 years, and a drought impact in single hot years. Local grazing impacts at grid cell level depend on selective habitat use of cattle. In turn, the attractiveness of grid cells for cattle grazing depends on their forage provision and local site characteristics (i.e., steepness of terrain, rock outcrops). By this means, the feedback loop between grazing impacts and vegetation succession is closed, from which the spatio-temporal distribution of productivity of herb layer vegetation types emerges during simulations.

The ratio of consumed forage and forage production in a grid cell was expressed as local utilization rate (LUR) and was based on a daily forage consumption of $18 \mathrm{~kg}$ DM per livestock unit. The same ratio calculated at pasture level was termed global utilization rate (GUR).

For a further detailed description of the model structure and the implementation of herb layer and tree layer dynamics, as well as rules for selective grazing, refer to Gillet (2008). Recent 
Table 2. Microclimate data overview for the plant growing season (AMJJAS) of 2010. Presented are mean parameter values for each altitude and pasture type.

\begin{tabular}{|c|c|c|c|c|c|c|c|c|c|}
\hline Altitude [m a.s.1.] & \multicolumn{3}{|c|}{1350} & \multicolumn{3}{|c|}{1010} & \multicolumn{3}{|c|}{570} \\
\hline Air temperature $\left[{ }^{\circ} \mathrm{C}\right]$ & & 10.0 & & & 12.3 & & & 15.1 & \\
\hline Air humidity [\%] & & 67.3 & & & 77.1 & & & 71.7 & \\
\hline Precipitation $[\mathrm{mm}]$ & & 707.6 & & & 599.7 & & & 524.6 & \\
\hline Pasture type ${ }^{\dagger}$ & $\mathrm{P}$ & WP & $\mathrm{F}$ & $\mathrm{P}$ & WP & $\mathrm{F}$ & $\mathrm{P}$ & WP & $\mathrm{F}$ \\
\hline Soil temperature $\left[{ }^{\circ} \mathrm{C}\right]$ & $11.2 \pm 0.2$ & $10.4 \pm 0.1$ & $9.7 \pm 0.1$ & $14.8 \pm 0.1$ & $13.3 \pm 0.1$ & $12.4 \pm 0.1$ & $17.5 \pm 0.2$ & $16.2 \pm 0.1$ & $15.3 \pm 0.2$ \\
\hline Soil moisture $[\%]^{\S}$ & $42.9 \pm 2.8$ & $41.3 \pm 2.3$ & $33.0 \pm 2.7$ & $28.9 \pm 1.1$ & $31.8 \pm 3.6$ & $31.8 \pm 0.5$ & $25.6 \pm 0.5$ & $25.7 \pm 1.1$ & $23.4 \pm 1.1$ \\
\hline
\end{tabular}

${ }^{\dagger}$ Pasture type codes, where P refers to unwooded pasture with $0 \%$ canopy shading, WP - sparsely wooded pasture with $40 \%$ canopy shading, and F densely wooded pasture with $80 \%$ canopy shading.

${ }^{\ddagger}, 8$ Reported values for soil temperature and moisture are means and standard errors for five replicate plots.

model refinements beyond this model description are given in Peringer et al. (2013).

\section{Design of simulations}

We simulated forage production under observed and projected climate in three separate wooded pastures in the region of Bullet, Switzerland. The pastures are located in the same landscape of the Swiss Jura Mountains as the experimental site, ca. $40 \mathrm{~km} \mathrm{NE}$ along the mountain crest. These pastures are adjacent to one other (Fig. 1); hence, they share identical climate but differ in grazing intensity and consequently vegetation structure. Les Planets Ouest (1200 m ASL, 46 ${ }^{\circ} 3^{\prime}$ ' $\left.\mathrm{N}, 6^{\circ} 55^{\prime} \mathrm{E}\right)$ is an intensively used commonage with 46 livestock units (LU) on 25.6 ha, resulting in $1.79 \mathrm{LU} / \mathrm{ha}$ for 170 days/year (see also Chételat et al. 2013). This pasture is practically treeless, and for the purpose of this study, is referred to as Intensive Wooded Pasture (IWP). Les Planets Milieu Est (1200 m ASL, 46 $84^{\prime} \mathrm{N}, 6^{\circ} 55^{\prime} \mathrm{E}$ ) is mostly open grassland but features some sparsely wooded pasture far in the northwest. It has a moderate stocking density of $22 \mathrm{LU}$ on 14.1 ha, resulting in $1.56 \mathrm{LU} / \mathrm{ha}$ for 135 days/year, and is referred to as Moderate Wooded Pasture (MWP). Les Cluds Sud (1200 $\mathrm{m}$ ASL, $46^{\circ} 84^{\prime} \mathrm{N}, 6^{\circ} 56^{\prime} \mathrm{E}$ ) is a mosaic pasture with several patches of woodland and is extensively grazed with $23 \mathrm{LU}$ on 23.3 ha, resulting in $0.99 \mathrm{LU} / \mathrm{ha}$ for 153 days/year. It is referred to as Extensive Wooded Pasture (EWP). Although ongoing socioeconomic developments will likely lead to reduced stocking of wooded-pastures (Huber et al. 2013), for the purpose of this study, we simulated constant stocking densities.

Time series of temperature and precipitation were derived from the regionalization of observed climate in the period 1950-2000 AD and two climate change scenarios from the Intergovernmental Panel on Climate Change Special Report Emissions Scenarios (IPCC-SRES 2000) for the period 2000$2100 \mathrm{AD}$, as provided by the Climatic Research Unit CRU of the University of East Anglia, Norwich, UK and the Tyndall Centre for Climate Change Research (regionalization by D. Schmatz, WSL-Switzerland, personal communication). We selected the moderate scenario $\mathrm{B} 2$ with $+4 \mathrm{~K}$ warming and the extreme scenario A1FI with $+8 \mathrm{~K}$ warming, assuming that a realistic future development will lie within the range between the two scenarios. The corresponding yearly mean temperatures are displayed in Fig. 2, together with the yearly mean temperatures of the vegetation growing period. The latter drive drought impact during simulations, whereas the average temperature of the last 50 years drives productivity increase. We initialized the model from aerial photographs taken in $2000 \mathrm{AD}$ and applied a 50-year spin-up period: 1950 2000 AD. Simulations run from 2000 on for a period of 50 years.

\section{RESULTS}

\section{Effects of increased temperature on aboveground biomass production at plot level}

Transplantation downslope exposed the plant communities in the experimental plots to an (expected) increase in ambient air temperature and reduced precipitation during the vegetation growing period (Table 2). Following this treatment, soil temperature generally increased, while soil moisture decreased (Table 2). Along the gradient in simulated tree cover, at each site soil temperature decreased almost linearly with approximately $1 \mathrm{~K}$ for each level of canopy shading $(0 \%$, $40 \%$, and $80 \%$ ). Shading also prevented soil water evaporation at lower altitudes compared to the control site. In the case of densely wooded pastures, soils kept up to $70 \%$ of their moisture content at $570 \mathrm{~m} \mathrm{ASL}$ and $96 \%$ at $1010 \mathrm{~m}$ ASL.

Results from the ANCOVA model indicated that AGB production along the transplantation gradient was significantly affected by pasture type $\left(P_{2.25}<0.001\right)$, and its interaction with the altitude of the transplantation site $\left(P_{4,25}<\right.$ $0.001)$. Furthermore, it was significantly affected by soil temperature $\left(P_{1,25}=0.016\right)$ and soil moisture $\left(P_{1,25}=0.008\right)$. AGB decreased significantly along the land use intensity gradient in the order unwooded > sparsely wooded > densely wooded pastures (Fig. 3). These differences were most evident at the control site at $1350 \mathrm{~m} \mathrm{ASL} \mathrm{but} \mathrm{were} \mathrm{weakened} \mathrm{at} \mathrm{warmer}$ 
climate where AGB production was stimulated in densely wooded pastures, reduced in unwooded pastures, and remained unchanged in sparsely wooded pastures (see Fig. 3, and the statistically significant interaction between pasture type and altitude). The transplantation altitude alone had no consistent effect on AGB across the pasture types.

Fig. 3. Change in aboveground biomass production in relation to (a) soil moisture and (b) soil temperature in unwooded pastures (circles), sparsely wooded pastures (squares), and densely wooded pastures (triangles). Altitudes of experimental plots were $570 \mathrm{~m}$ ASL (black symbols), $1010 \mathrm{~m}$ ASL (grey symbols), and $1350 \mathrm{~m}$ ASL (empty symbols).

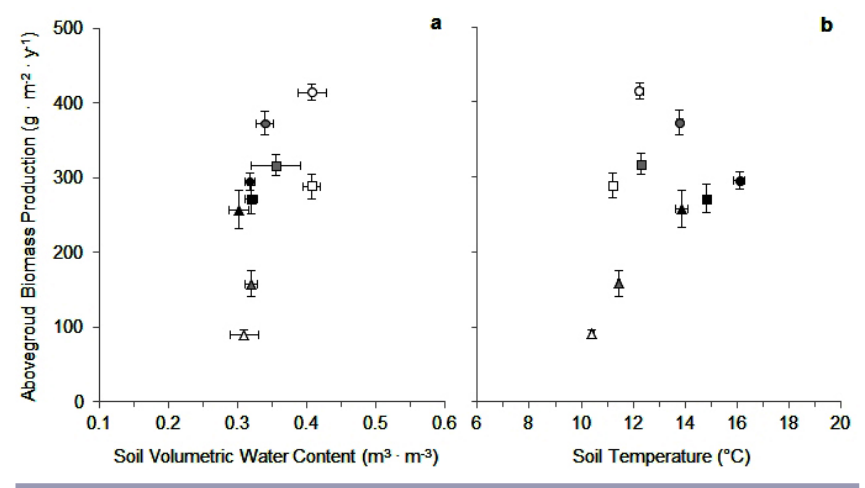

Fitting a linear regression model through the biomass data allowed us to estimate the influence of land use and climate parameters on pasture productivity. The resulting model $\left(R^{2}=\right.$ $\left.0.85, P_{3,41}<0.001\right)$ is given in Eq. 2:

$A G B=$

$55.670-3.291 \Delta T-0.456$ TreeCover +0.070 TreeCover $\Delta T$

This equation expresses the production of herbaceous biomass, AGB, as a function of percent tree cover (TreeCover), air temperature anomaly $(\Delta T)$, and their interaction. All parameter estimates, including the model's intercept, were highly significant $\left(P_{1.41}<0.001\right)$, and hence were incorporated into the WoodPaM model in the form of a factor applied to the first estimate of forage production in the grassland-forest mosaic (Methods: Spatially explicit simulation model).

\section{Effects of temperature anomalies on forage production at landscape level}

Simulated time series of GUR followed distinct trajectories according to management intensity within each of the studied pastures (Fig. 4). Most obvious was the trivial effect of a higher utilization rate with higher stocking density, which led to well- separated curves for each pasture. The spin-up period ended around year 1980, and realistic utilization rates were simulated for extensive (EWP: 70\%), moderate (MWP: 80\%), and intense pastures (IWP: 100\%). A utilization rate of $100 \%$ represents an optimal stocking density in an economic sense because all available forage is consumed. A utilization rate less than $100 \%$ indicates the presence of undergrazed patches, which are typical in extensively grazed pastures, and provides niches where shrubs and woods can develop and form the specific landscape mosaic of pasture-woodlands.

Fig. 4. Global utilization rates (GUR) of produced forage for the three pastures and the two Intergovernmental Panel on Climate Change Special Report Emissions Scenarios (IPCC-SRES 2000) climate change scenarios: (a) B2 and (b) A1FI. Pastures are Les Cluds Sud (EWP:light grey curve), Les Planets Milieu Est (MWP:dark grey curve), and Les Planets Ouest (IWP: black curve).
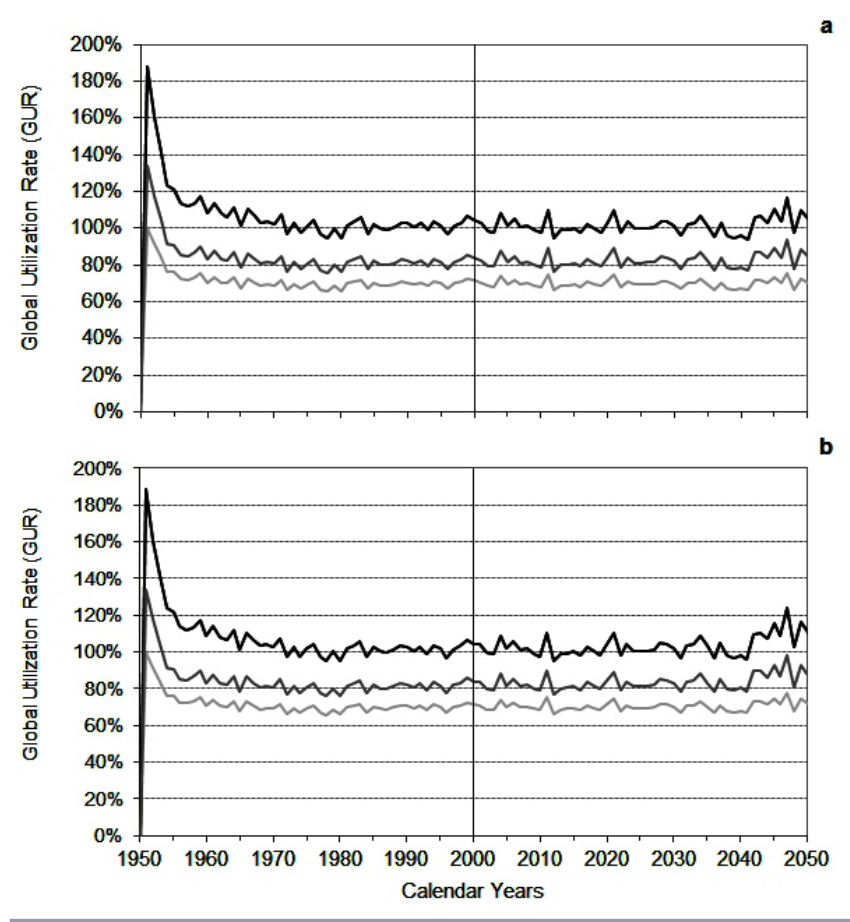

From year 2000 onwards, utilization rates did not decrease, as one would expect from the increase in productivity following the prolongation of the vegetation growing period with climate change (Fig. 2). The rapid temperature rise and subsequent increase in simulated drought due to an increasing number of years with hot summers compensated for this effect. In the course of time, the utilization rates of IWP and MWP started to fluctuate with increasing amplitude, and IWP peak values passed above the threshold of $100 \%$. To the contrary, the 
Table 3. Simulated impact of drought on global utilization rates (GUR) in the three studied wood-pastures. An arbitrarily comparison of a hot year $\left(2021\right.$, growing season mean air temperature $\left.11.3{ }^{\circ} \mathrm{C}\right)$ to a normal year $(2022$, growing season mean air temperature $9.6^{\circ} \mathrm{C}$ ) under the B2 IPCC-SRES scenario. Long-term (1961-2010) average of the growing season temperature is $9.0^{\circ} \mathrm{C}$.

\begin{tabular}{lccc}
\hline \hline & $\begin{array}{c}\text { GUR of EWP } \\
\text { Les Cluds Sud) }\end{array}$ & $\begin{array}{c}\text { GUR of MWP } \\
\text { (Les Planets Milieu Est) } \\
\text { [\%] }\end{array}$ & $\begin{array}{c}\text { GUR of IWP } \\
\text { (Les Planets Ouest) } \\
\text { [\%] }\end{array}$ \\
\hline Simulation year 2021 & 74.4 & 89.1 & 110.1 \\
Simulation year 2022 & 67.8 & 78.7 & 97.6 \\
$\Delta$ GUR between years 2021 and 2022 & 6.7 & 10.4 & 12.5 \\
Average GUR in the period 1980-2000 & 70.0 & 83.8 & 104.4 \\
$\Delta$ GUR between years 2021 and 2022 corrected $^{\dagger}$ for average GUR & 9.5 & 12.4 & 11.9 \\
\hline
\end{tabular}

Dividing the simulated GUR by the average GUR corrects for the trivial effect of lower drought impacts in extensive pastures.

utilization rate of EWP always remained below $100 \%$ and fluctuations were far smaller. For the drastic warming scenario A1FI $(+8 \mathrm{~K})$, such effects were even more pronounced, especially in the projected heat wave in simulation years 2042 2047.

Overall, for current stocking densities, simulations of extensive pastures showed a continuous provision of sufficient forage, while in intense pastures, scarcity of forage was indicated. The stable forage provision in EWP (i.e., low amplitude of projected GUR in Fig. 4) might appear trivial due to intrinsically low stocking densities in this pasture. Nevertheless, the stimulated AGB production in its forested landscape patches did provide a quantitative buffering capacity against heat waves. Such a contribution of landscape heterogeneity to ecosystem process resilience is exemplified through the comparison of a pair of simulated years with hot (2021) and cool (2022) temperatures from the simulation continuum of IPCC-SRES climate change scenario B2 (Fig. 2 ). We chose two consecutive years in order to compare a quasi identical landscape structure. Within the treeless IWP in the hot year 2021, forage production decreased with drought causing an increase of $12.5 \%$ in GUR (Table 3, Fig. 5). Similar drought impacts on forage production were recognizable within the grasslands of MWP and EWP (Fig. 5); however, the utilization rate in EWP, which is a true forest-grassland mosaic, increased by only $6.7 \%$ in GUR (Table 3). An additional mathematical correction for the potential bias of extensive pastures being less prone to overshooting GUR levels in response to forage scarcity was implemented by dividing GUR values for a given year by the long-term average GUR. The corrected differences in GUR values between the two years remained higher in IWP and MWP (11.9 and 12.4, respectively) compared to those in EWP(9.5), which indicated the simulated buffering potential of wood-pastures (Table 3 ).
Fig. 5. Output maps of forage production and local utilization rate (percentage consumed forage) in two arbitrarily chosen years-a hot one (2021) and a cool one (2022), based the moderate climate change scenario B2 with contrasting average temperatures in the vegetation period $(\Delta$ $1.5 \mathrm{~K})$. Darker tones indicate higher values of the respective parameters.

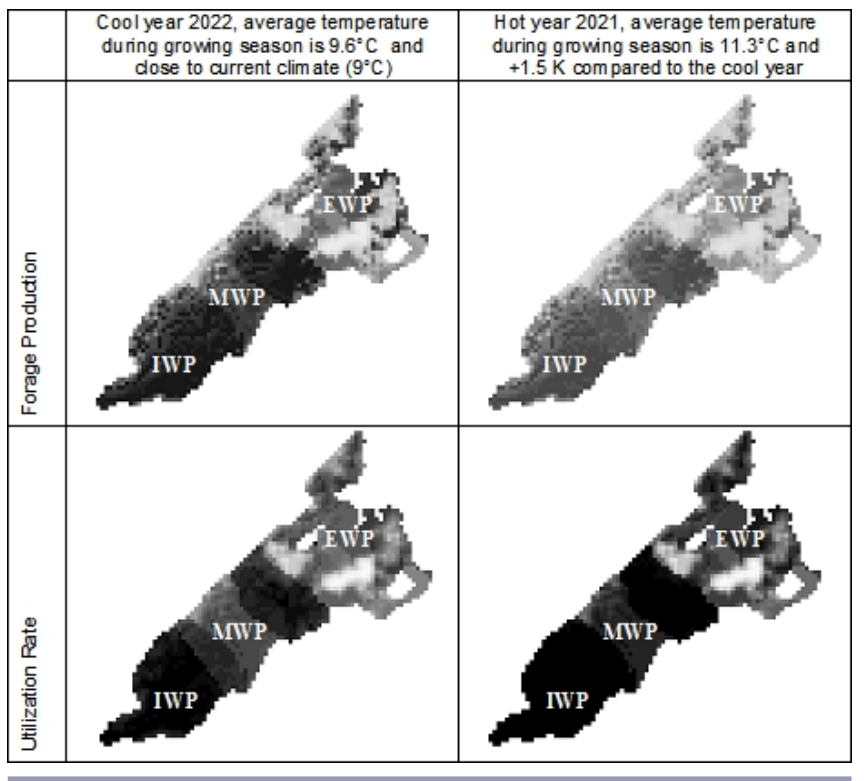

\section{DISCUSSION}

\section{Distinct effects of climate change on herbaceous production across land use types}

Our experimental study was novel for directly comparing climate change impacts on several neighboring grasslands that were experiencing different intensities of management, which were manifested by a gradient of forest canopy cover and herbaceous species composition. The results unequivocally 
displayed the decline in herbaceous productivity in open pastures in contrast to stable and even increasing productivity in forested pastures under warmer climate. This pattern became apparent after only one year of experimental treatment, which emphasizes the importance of stochastic heat waves for the functioning of pasture-woodland ecosystems. As a result of the transplantation treatment, open pastures experienced disproportionately stronger drought effects than the two wood-pasture types, and this was driven mainly by decreased soil moisture availability. Even though our simplistic design for shading of the mesocosms certainly did not encompass all the microclimate effects of a real tree canopy (i.e., ambient humidity, wind interception, canopy leachate, litter deposition, or underground competition for resources), we believe our results on herbaceous production are robust due to the appropriate use of control plots and the overall short time span of the treatment, which prevented accumulation of confounding carry-over effects.

One of the most prominent factors driving the reduction in AGB was the decrease in soil moisture availability during the plant growing season. Whereas soil temperature increased linearly with warmer climate for all pasture types, soil humidity was affected mainly in the unwooded pasture plots, which was paralleled by a decrease in standing plant AGB. Moreover, most of this AGB had already senesced shortly after the peak growing season due to drought (Normalized Difference Vegetation Index measurements, unpublished data). This phenomenon arose from intensified evapotranspiration in open-canopy plots in comparison to the shaded ones, where the mesh covers had adequately served their "forest-like" purpose in limiting energy exchange with the atmosphere during the hot summer months (Teuling et al. 2010).

An alternative explanation could be that intensive farming (Körner et al. 2006), coupled with high fertilization levels and impeded successional development (Grime et al. 2000), played a role in rendering intensively managed open pastures more vulnerable to climate change. One could speculate that those grassland communities, composed of fast-growing species with access to high nutrient availability, are more responsive to environmental change. This scenario, however, was not explicitly tested in our experimental design (no fertilization manipulations) and remains only hypothetical. Moreover, we consider unwooded pastures to be intensively managed, but more so in relative terms in comparison to wooded ones, since they are generally subalpine pastures rather than farming fields.

\section{Landscape patterns of forage provision under climate change}

Our approach to incorporating experimental results into a process-based simulation model of wooded pastures merits more than a simple extrapolation across spatial scales (from plot to landscape levels). Since biomass production of grasslands forms represents the base of WoodPaM simulations, climate change impacts on primary production mechanistically determine forage availability for cattle, which in turn shapes landscape structure via selective grazing behavior (Kohler et al. 2006). Regardless of the limitations of our experimental design, which did not account for plausible interaction between precipitation and temperature, we do not expect a qualitative bias in our interpretations. Our confidence comes from the locally observed and predicted strong negative correlation between these two climatic factors; hence, we included only temperature in our predictive model for AGB production. Even though we based our choice of transplantation gradient on both current weather observations and climate predictions, we could not account for ecosystem responses to future warm and wet, or cold and dry plant growing seasons.

While other studies of climate change impacts on wooded pastures rely mainly on the climate sensitivity of tree species (Peringer et al. 2013), ours focused on the functioning of grasslands. The design of simulations encompassed a much shorter time frame from 2000 to $2050 \mathrm{AD}$ - a period short enough to detect climatic stress while assuming no plant species adaptation (development of drought-adapted ecotypes), or significant community change through immigration. Even though this assumption may appear unrealistic for the last decades of simulation, we considered three reasons for it: (1) there is no simple way to implement evolutionary and dispersal processes for grassland species in the model; (2) species shift from lowland following climate change is probably very slow in this area due to forest barriers to the dispersal of herbaceous species; and (3) phenotypic plasticity and genetic polymorphism of established plant populations is likely to allow yet some adaptation to drought stress due to the long history (ecological continuity) of these mountain pastures. Furthermore, this period is too short to produce any substantial shift in the tree layer and thus the landscape structure (see Peringer et al. [2013] for long-term dynamics of climate change). Nevertheless, one should bear in mind that, in the long run, impacts of climate change on grassland productivity could produce feedback on landscape structure due to adaptive grazing behavior of cattle (Smit et al. 2007, Vandenberghe et al. 2007, Vandenberghe et al. 2009). In hot years, depleted forage resources in open pastures would provoke cattle grazing in the forest understory, where drought impacts were found to be smaller and forage would still be available. Forest regeneration would hence be put at stake and landscape structural dynamics could be expected to shift towards a more open landscape. Such a development would counteract projected forest encroachment and canopy thickening (Peringer et al. 2013), thus rendering a stable forage provision in the far future.

Our simulations showed that in extensive grazing systems, it was not only the generally lower stocking density but also the 
resulting grassland-forest mosaic that contributed to the robust provision of forage. The observed stable AGB production in sparsely wooded pastures, and increasing production in densely wooded pastures in the face of warming and drought, were in sharp contrast with the decreased AGB in unwooded pastures. Consequently, the apparent advantage in terms of productivity of unwooded pasture diminished with drought, and wooded pastures became a forage source of similar importance. In view of the relatively large area that sparsely and densely wooded pastures cover in extensively stocked pastures, such formerly unproductive patches showed a clear potential to compensate for the breakdown of productivity within open grasslands.

Given that mosaic emergence is a process that occurs over centuries (Gillet 2008, Peringer et al. 2013), such resilience of the system is a precious good because it is rapidly destroyed but slowly re-established. Chételat et al. (2013) show that landscape transformations of such great magnitude could result, for example, from higher wood and food demands (for example, during war time) and from natural events (storms, droughts, bark beetle outbursts). Similar conclusions about the beneficial role of tree canopy on understory microclimate during drought have been made for agroforestry systems (Powell and Bork 2006). Across the landscape, spatial variation itself stimulates ecosystem resilience and resistance to drought. Godfree et al. (2011) show that naturally occurring extreme climatic events such as drought can be mitigated through the protective role of heterogeneous environments. This concept is shared by Foley et al. (2005) who advocate the maintenance of a diverse portfolio of ecosystem services by a single ecosystem, such that sustainable land use strategies could be implemented for both short- and long-term needs. We show that in the case of subalpine wooded pastures, this can be accomplished through the preservation of the mosaic landscape. It is, nevertheless, acknowledged that decisions about the future of cultural landscapes (i.e., wood-pastures) come from stakeholders rather than scientists, and that such a stability requires both maintenance of historically established agricultural practices (Küster 2004) and adaptive management, including change in policies (Huber et al. 2013). Either courses of intensification or abandonment would place the ecosystem's stability at stake and disrupt the delivery of its prime ecosystem services.

\section{CONCLUSION}

In summary, different grassland types within the pasturewoodland landscape of the Swiss Jura Mountains were shown to exhibit a strictly nonuniform response to climate change in terms of herbaceous forage provision. The mosaic patchiness of the landscape would be a valuable asset in the face of climate warming, and its inherent diversity may hold the key to sustainable land use management. Presented were empirical and modeling evidence that wood-pastures may provide forage for livestock in a robust way by buffering impacts of climate change for the next decades. We believe that this property of the landscape should hence be credited in order to avoid any future landscape segregation and associated economic and cultural impacts.

Responses to this article can be read online at: http://www.ecologyandsociety.org/issues/responses. php/4974

\section{Acknowledgments:}

This work was supported by the CCES (Competence Center Environment and Sustainability of the ETH Domain, Switzerland) as part of the Mountland project, and by the State Secretariat for Education and Research (SER C07.0112) in the framework of the COST Action FP0603. We thank Arboretum National d'Aubonne, Commune of St-George (VD), Parc Jurassien Vaudois, Fondation Les Bois Chamblard for their logistics and infrastructure support. Special thanks go also to Dr. Silvana Siehoff who provided us with constructive comments on the manuscript and to various people from the ECOS laboratory who gave a precious hand during fieldwork.

\section{LITERATURE CITED}

Barbezat, V., and J. F. Boquet. 2008. Gestion intégrée des paysages sylvo-pastoraux de l'Arc jurassien-Manuel (Hankbook). Conférence TransJurassienne. La Chaux-deFonds, Besançon.

Beniston, M. 2009. Decadal-scale changes in the tails of probability distribution functions of climate variables in Switzerland. International Journal of Climatology 29:13621368. http://dx.doi.org/10.1002/joc.1793

Beniston, M., H. F. Diaz, and R. S. Bradley. 1997. Climatic change at high elevation sites: an overview. Climatic Change 36:233-251. http://dx.doi.org/10.1023/A:1005380714349

Beniston, M., D. B. Stephenson, O. B. Christensen, C. A. T. Ferro, C. Frei, S. Goyette, K. Halsnaes, T. Holt, K. Jylha, B. Koffi, J. Palutikof, R. Scholl, T. Semmler, and K. Woth. 2007. Future extreme events in European climate: an exploration of regional climate model projections. Climatic Change 81:7195. http://dx.doi.org/10.1007/s10584-006-9226-z

Bowman, W. D., J. R. Gartner, K. Holland, and M. Wiedermann. 2006. Nitrogen critical loads for alpine vegetation and terrestrial ecosystem response: Are we there yet? Ecological Applications 16:1183-1193. http://dx.doi. org/http://dx.doi.org/10.1890/1051-0761(2006)016[1183:NCLFAV] 2.0.CO;2

Breeuwer, A., M. Heijmans, B. J. M. Robroek, and F. Berendse. 2010. Field simulation of global change: 
transplanting northern bog mesocosms southward. Ecosystems 13:712-726. http://dx.doi.org/10.1007/s10021-010-9349-y

Brock, M. T., and C. Galen. 2005. Drought tolerance in the alpine dandelion, Taraxacum ceratophorum (Asteraceae), its exotic congener T. officinale, and interspecific hybrids under natural and experimental conditions. American Journal of Botany 92:1311-1321. http://dx.doi.org/10.3732/ajb.92.8.1311

Bruelheide, H. 2003. Translocation of a montane meadow to simulate the potential impact of climate change. Applied Vegetation Science 6:23-34. http://dx.doi.org/10.1111/ j.1654-109X.2003.tb00561.x

Buchner, O., and G. Neuner. 2003. Variability of heat tolerance in alpine plant species measured at different altitudes. Arctic, Antarctic and Alpine Research 35:411-420. http://dx.doi.org/10.1657/1523-0430(2003)035[0411:VOHTIA] 2.0.CO;2

Buttler, A., F. Kohler, and F. Gillet. 2009. The Swiss mountain wooded pastures: patterns and processes. Pages 377-396 in A. Rigueiro-Rodrigues, J. McAdam, and M. R. MosqueraLosada, editors. Agroforestry in Europe, current status and future prospects. Springer, Netherlands. http://dx.doi. org/10.1007/978-1-4020-8272-6 19

CH2011. 2011. Swiss climate change scenarios CH2O11. C2SM, MeteoSwiss, ETH, NCCR Climate, and OcCC, Zurich, Switzerland.

Chételat, J., M. Kalbermatten, K. S. M. Lannas, T. Spiegelberger, J. B. Wettstein, F. Gillet, A. Peringer, and A. Buttler. 2013. A contextual analysis of land-use and vegetation changes in two wooded pastures in the Swiss Jura Mountains. Ecology and Society 18(1): 39. http://dx.doi.org/10.5751/ ES-05287-180139

Ciais, P., M. Reichstein, N. Viovy, A. Granier, J. Ogee, V. Allard, M. Aubinet, N. Buchmann, C. Bernhofer, A. Carrara, F. Chevallier, N. De Noblet, A. D. Friend, P. Friedlingstein, T. Grunwald, B. Heinesch, P. Keronen, A. Knohl, G. Krinner, D. Loustau, G. Manca, G. Matteucci, F. Miglietta, J. M. Ourcival, D. Papale, K. Pilegaard, S. Rambal, G. Seufert, J. F. Soussana, M. J. Sanz, E. D. Schulze, T. Vesala, and R. Valentini. 2005. Europe-wide reduction in primary productivity caused by the heat and drought in 2003. Nature 437:529-533. http://dx.doi.org/10.1038/nature03972

Dufour, A., F. Gadallah, H. H. Wagner, A. Guisan, and A. Buttler. 2006. Plant species richness and environmental heterogeneity in a mountain landscape: effects of variability and spatial configuration. Ecography 29:573-584. http://dx. doi.org/10.1111/j.0906-7590.2006.04605.x

Dunne, J. A., J. Harte, and K. J. Taylor. 2003. Subalpine meadow flowering phenology responses to climate change: integrating experimental and gradient methods. Ecological
Monographs 73:69-86. http://dx.doi.org/10.1890/0012-9615 (2003)073[0069:SMFPRT]2.0.CO;2

Dunne, J. A., S. R. Saleska, M. L. Fischer, and J. Harte. 2004. Integrating experimental and gradient methods in ecological climate change research. Ecology 85:904-916. http://dx.doi. org/10.1890/03-8003

Etienne, M., editor. 1996. Western European silvopastoral systems. INRA Editions, Paris, France.

Federal Office for the Environment and Federal Statistical Office (FOEN/FSO). 2011. Environment Switzerland 2011. Bern and Neuchâtel, Switzerland.

Foley, J. A., R. DeFries, G. P. Asner, C. Barford, G. Bonan, S. R. Carpenter, F. S. Chapin, M. T. Coe, G. C. Daily, H. K. Gibbs, J. H. Helkowski, T. Holloway, E. A. Howard, C. J. Kucharik, C. Monfreda, J. A. Patz, I. C. Prentice, N. Ramankutty, and P. K. Snyder. 2005. Global consequences of land use. Science 309:570-574. http://dx.doi.org/10.1126/ science. 1111772

Gillet, F. 2008. Modelling vegetation dynamics in heterogeneous pasture-woodland landscapes. Ecological Modelling 217:1-18. http://dx.doi.org/10.1016/j. ecolmodel.2008.05.013

Gillet, F., O. Besson, and J.-M. Gobat. 2002. PATUMOD: a compartment model of vegetation dynamics in wooded pastures. Ecological Modelling 147:267-290. http://dx.doi. org/10.1016/S0304-3800(01)00427-6

Gillet, F., and J. D. Gallandat. 1996. Wooded pastures of the Jura Mountains. Pages 37-53 in M. Etienne, editor. Western European silvopastoral systems. INRA Editions, Paris, France.

Gillet, F., B. Murisier, A. Buttler, J.-D. Gallandat, and J.-M. Gobat. 1999. Influence of tree cover on the diversity of herbaceous communities in subalpine wooded pastures. Applied Vegetation Science 2:47-54. http://dx.doi. org/10.2307/1478880

Godfree, R., B. Lepschi, A. Reside, T. Bolger, B. Robertson, D. Marshall, and M. Carnegie. 2011. Multiscale topoedaphic heterogeneity increases resilience and resistance of a dominant grassland species to extreme drought and climate change. Global Change Biology 17:943-958. http://dx.doi.org/10.1111/ j.1365-2486.2010.02292.x

Grime, J. P., V. K. Brown, K. Thompson, G. J. Masters, S. H. Hillier, I. P. Clarke, A. P. Askew, D. Corker, and J. P. Kielty. 2000. The response of two contrasting limestone grasslands to simulated climate change. Science 289:762-765. http://dx. doi.org/10.1126/science.289.5480.762 
Harte, J., and R. Shaw. 1995. Shifting dominance within a montane vegetation community-results of a climatewarming experiment. Science 267:876-880. http://dx.doi. org/10.1126/science.267.5199.876

Hobbie, S. E., and F. S. Chapin, III. 1998. An experimental test of limits to tree establishment in Arctic tundra. Journal of Ecology 86:449-461. http://dx.doi.org/10.1046/

j.1365-2745.1998.00278.x

Huber, R., S. Briner, A. Peringer, S. Lauber, R. Seidl, A. Widmer, F. Gillet, A. Buttler, Q. Beo Le, and C. Hirschi. 2013. Modeling social-ecological feedback effects in the implementation of payments for environmental services in pasture-woodlands. Ecology and Society Vol. 18 In press.

Inouye, D. W. 2008. Effects of climate change on phenology, frost damage, and floral abundance of montane wildflowers. Ecology 89:353-362. http://dx.doi.org/10.1890/06-2128.1

Intergovernmental Panel on Climate Change (IPCC). 2000. Special report emission scenarios. Cambridge University Press, Geneva, Switzerland.

Intergovernmental Panel on Climate Change (IPCC). 2007. Climate change 2007: synthesis report. Contribution of Working Groups I, II and III to the Fourth Assessment Report of the Intergovernmental Panel on Climate Change. Geneva, Switzerland.

Johnson, D., J. Vachon, A. J. Britton, and R. C. Helliwell. 2011. Drought alters carbon fluxes in alpine snowbed ecosystems through contrasting impacts on graminoids and forbs. New Phytologist 190:740-749. http://dx.doi. org/10.1111/j.1469-8137.2010.03613.x

Kohler, F., F. Gillet, S. Reust, H. H. Wagner, F. Gadallah, J. M. Gobat, and A. Buttler. 2006. Spatial and seasonal patterns of cattle habitat use in a mountain wooded pasture. Landscape Ecology 21:281-295. http://dx.doi.org/10.1007/s10980-005-0144-7

Körner, C. 2003. Alpine plant life: functional plant ecology of high mountain ecosystems. Springer, Berlin Heidelberg, New York.

Körner, C., G. Nakhutsrishvili, and E. Spehn. 2006. Highelevation land use, biodiversity, and ecosystem functioning. Pages 3-21 in E. Spehn, M. Liberman, and C. Körner, editors. Land use change and mountain biodiversity. CRC Press, Boca Raton, Florida, USA. http://dx.doi.org/10.1201/9781420002874. ch1

Küster, H. 2004. Cultural landscapes. Pages 1-11 in M. Dieterich and J. Straaten, editors. Cultural landscapes and land use. Springer, The Netherlands.

Mariotte, P., C. Vandenberghe, F. Hagedorn, and A. Buttler. 2013. Subordinate plant species enhance community resistance against drought in grassland ecosystems. Journal of Ecology http://www.journalofecology.org/view/0/index. $\underline{\mathrm{html}}$

Miéville-Ott, V., and V. Barbezat. 2005. Perception du pâturage boisé: résultats d'un sondage effectué au Communal de La Sagne NE. Schweizerische Zeitschrift fur Forstwesen 156:1-12. http://dx.doi.org/10.3188/szf.2005.0001

Nogués-Bravo, D., M. B. Araújo, M. P. Errea, and J. P. Martinez-Rica. 2007. Exposure of global mountain systems to climate warming during the 21st century. Global Environmental Change-Human and Policy Dimensions 17:420-428. http://dx.doi.org/10.1016/j.gloenvcha.2006.11.007

Parry, M. L. 2000. Assessment of potential effects and adaptations for climate change in Europe: the Europe ACACIA project. Jackson Environmental Institute, University of East Anglia, Norwich, UK.

Peringer, A., S. Siehoff, J. Chételat, T. Spiegelberger, A. Buttler, and F. Gillet. 2013. Past and future landscape dynamics in pasture-woodlands of the Swiss Jura Mountains under climate change. Ecology and Society Vol. 18 In press.

Powell, G. W., and E. W. Bork. 2006. Aspen canopy removal and root trenching effects on understory vegetation. Forest Ecology and Management 230:79-90. http://dx.doi. org/10.1016/j.foreco.2006.04.021

R Development Core Team. 2012. R version 2.14.1.

Reichstein, M., P. Ciais, D. Papale, R. Valentini, S. Running, N. Viovy, W. Cramer, A. Granier, J. OgÉE, V. Allard, M. Aubinet, C. Bernhofer, N. Buchmann, A. Carrara, T. GrÜNwald, M. Heimann, B. Heinesch, A. Knohl, W. Kutsch, D. Loustau, G. Manca, G. Matteucci, F. Miglietta, J. M. Ourcival, K. Pilegaard, J. Pumpanen, S. Rambal, S. Schaphoff, G. Seufert, J. F. Soussana, M. J. Sanz, T. Vesala, and M. Zhao. 2007. Reduction of ecosystem productivity and respiration during the European summer 2003 climate anomaly: a joint flux tower, remote sensing and modelling analysis. Global Change Biology 13:634-651. http://dx.doi.org/10.1111/ j.1365-2486.2006.01224.x

Schär, C., P. L. Vidale, D. Lûthi, C. Frei, C. Haberli, M. A. Liniger, and C. Appenzeller. 2004. The role of increasing temperature variability in European summer heatwaves. Nature 427:332-336. http://dx.doi.org/10.1038/nature02300

Scheepens, J. F., E. S. Frei, and J. Stocklin. 2010. Genotypic and environmental variation in specific leaf area in a widespread alpine plant after transplantation to different altitudes. Oecologia 164:141-150. http://dx.doi.org/10.1007/ s00442-010-1650-0

Sebastia, M.-T. 2007. Plant guilds drive biomass response to global warming and water availability in subalpine grassland. Journal of Applied Ecology 44:158-167. http://dx.doi. org/10.1111/j.1365-2664.2006.01232.x 
Smit, C., C. Vandenberghe, J. den Ouden, and H. MûellerSchäerer. 2007. Nurse plants, tree saplings and grazing pressure: changes in facilitation along a biotic environmental gradient. Oecologia 152:265-273. http://dx.doi.org/10.1007/ s00442-006-0650-6

Soudzilovskaia, N. A., V. G. Onipchenko, J. H.C. Cornelissen, and R. Aerts. 2007. Effects of fertilisation and irrigation on 'foliar afterlife' in alpine tundra. Journal of Vegetation Science 18:755-766. http://dx.doi.org/10.1111/j.1654-1103.2007.tb02591. $\underline{x}$

Spiegelberger, T., F. Gillet, B. Amiaud, A. Thébault, P. Mariotte, and A. Buttler. 2012. How do plant community ecologists consider the complementarity of observational, experimental and theoretical modelling approaches? Plant Ecology and Evolution 145:4-12. http://dx.doi.org/http://dx. doi.org/10.5091/plecevo.2012.699

Teuling, A. J., S. I. Seneviratne, R. Stockli, M. Reichstein, E. Moors, P. Ciais, S. Luyssaert, B. van den Hurk, C. Ammann, C. Bernhofer, E. Dellwik, D. Gianelle, B. Gielen, T. Grunwald, K. Klumpp, L. Montagnani, C. Moureaux, M. Sottocornola, and G. Wohlfahrt. 2010. Contrasting response of European forest and grassland energy exchange to heatwaves. Nature Geoscience 3:722-727. http://dx.doi.org/10.1038/ngeo950

van Ruijven, J., and F. Berendse. 2010. Diversity enhances community recovery, but not resistance, after drought. Journal of Ecology 98:81-86. http://dx.doi.org/10.1111/

j.1365-2745.2009.01603.x

Vandenberghe, C., F. Freléchoux, M.-A. Moravie, F. Gadallah, and A. Buttler. 2007. Short-term effects of cattle browsing on tree sapling growth in mountain wooded pastures. Plant Ecology 188:253-264. http://dx.doi.org/10.1007/ s11258-006-9160-1

Vandenberghe, C., C. Smit, M. Pohl, A. Buttler, and F. Frelechoux. 2009. Does the strength of facilitation by nurse shrubs depend on grazing resistance of tree saplings? Basic and Applied Ecology 10:427-436. http://dx.doi.org/http://dx. doi.org/10.1016/j.baae.2008.08.009

Wieder, R. K., and J. B. Yavitt. 1994. Peatlands and global climate-change: insights from comparative studies of sites situated along a latitudinal gradient. Wetlands 14:229-238. http://dx.doi.org/10.1007/BF03160660

Zhang, Y. Q., and J. M. Welker. 1996. Tibetan alpine tundra responses to simulated changes in climate: aboveground biomass and community responses. Arctic and Alpine Research 28:203-209. http://dx.doi.org/10.2307/1551761 